\title{
Predicting Bread Quality (Bread Loaf Volume and Crumb Texture)
}

\author{
Renata Różyto*, Janusz Laskowski \\ Department of Equipment Operation and Maintenance in the Food Industry, University of Life Sciences, \\ ul. Doświadczalna 44, 20-280 Lublin, Poland
}

Key words: wheat flour, dough, alveograph properties, texture properties, breadcrumb

The objective of this study was to evaluate the predictive power of flour and dough alveograph properties in simultaneous determination of bread loaf volume and crumb texture. Ten Polish spring wheat cultivars were used in this study. Flour was determined for protein content, wet gluten content, gluten elasticity, Zeleny sedimentation volume, falling number, and ash content. Alveograph properties of the dough were strength, tenacity, extensibility, and elasticity resistance. After the straight dough bread making test, the loaf volume and breadcrumb texture were measured. Textural properties of the breadcrumbs were tested by texture profile analysis (TPA). The parameters recorded were hardness, cohesiveness, and gumminess. The results were analysed statistically to develop effective predictive models, the stepwise regression procedure and canonical analysis were applied. The results from the experimental tests indicated that among the variables, the flour protein content, the Zeleny sedimentation index, the flour falling number, and dough strength were the main factors affecting the textural properties of the breadcrumb alone and with the bread loaf volume. The results showed that a combination of several flour and dough alveograph properties could predict bread quality.

\section{NOMENCLATURE}

Flour properties: $A_{f}$ - Flour ash content, \%, FN -Flour falling number, $s, \mathrm{G}_{\mathrm{f}}-$ Flour gluten content, $\%, \mathrm{GE}_{\mathrm{f}}-$ Flour gluten elasticity, $\mathrm{mm}, \mathrm{P}_{\mathrm{f}_{-}}$Flour protein content, $\%, \mathrm{Si}-$ Zeleny sedim. index, $\mathrm{mL}$. Dough properties: Ie - Elasticity resistance, -, L- Extensibility, $\mathrm{mm}, \mathrm{P}-$ Tenacity, $\mathrm{mm}_{\mathrm{H} 20}$, W- Strength, $10^{-4} \mathrm{~J}$. Bread properties: $\mathrm{C}_{\mathrm{b}}-\mathrm{Crumb}$ cohesiveness, - $\mathrm{G}_{\mathrm{b}}-$ Crumb gumminess, $\mathrm{N}, \mathrm{H}_{\mathrm{b}}$ - Crumb hardness, $\mathrm{N}$, $\mathrm{V}_{\mathrm{b}}$ - Loaf bread volume, $\mathrm{cm}^{3}$.

\section{INTRODUCTION}

Wheat is a principal cereal used for bread making, because of its wheat-baking properties, as well as its valuable chemical constitution. Nowadays, the quality of raw material is the most important problem for bakers. They require flour, which has the ability to produce bread with large loaf volume and good crumb texture, with good maintenance properties. Research on determining relationships between the flour properties and the characteristics of the final product remain a challenge for scientists.

Bread properties are very often influenced by flour components [Dowell et al., 2008; Edwards et al., 2007; Perez Borla et al., 2004] and the rheological properties of the dough [Andersson et al., 1994; Armero \& Collar, 1997; Bloksma, 1990; Gras et al., 2000; Oliver \& Allen, 1992; Phan-Thien \& Safari-

\footnotetext{
* Corresponding author:

E-mail: renata.rozylo@up.lublin.pl (R. Różyło)
}

Ardi, 1998; Stampfli \& Nersten, 1995; Tronsomo et al., 2003; Wilkstrőm \& Bohlin, 1999]. Edwards et al. [2007] demonstrated that the hearth bread baking quality of durum wheat varied in protein composition and physical dough properties. Dowell et al. [2008] estimated the attributes of bread quality (loaf volume, bake mix time, bake water absorption, and crumb score) by using grain, flour, and dough quality. The importance of protein and gluten content as well as its quality and baking properties are well documented [Karolini-Skardzińska et al., 2001; Færgestad et al., 1999, 2000]. Some researchers showed the Zeleny sedimentation volume [Cacak-Pietrzak et al., 1999; Duma, 1992] and falling number influence on bread properties [Czubaszek et al., 2001]. In a majority of the mentioned studies the quality of bread was assessed by loaf volume, and the breadcrumb properties were taken into consideration only in a minority of these studies.

Several recent studies have described the relation between the rheological properties of dough and properties of breadcrumbs [Dowell et al., 2008; Tronsomo et al., 2003; Janssen et al., 1996; Scanlon et al., 2000]. The authors did not determine the relation between flour properties and alveograph parameters of the dough or the textural properties of the breadcrumb. Alveograph parameters are obligatorily used as quality indicators of wheat [Dziki \& Laskowski, 2003; Laskowski \& Różyło, 2004] and should be taken into consideration.

In spite of several studies that have focused on determining the relationship between the flour and dough and bread properties, there is no simple model that shows the specific flour and dough properties that have an impact on the com- 
plex bread characteristics (including bread loaf volume and texture of breadcrumb).

In consideration of this, the objective of this study was to determine the relationship between both flour components and the alveograph parameters of the dough and the loaf volume and breadcrumb texture. To develop effective predictive models, the stepwise regression procedure and canonical analysis was applied. Additionally the best and the worst cultivars to wheat bread production were characterised.

\section{MATERIALS AND METHODS}

\section{Materials}

Ten Polish spring wheat cultivars (Hezja, Kontesa, Torka, Zebra, Eta, Santa, Nawra, Jasna, Koksa, Kosma) were used in this study. The cultivars were grown in Końskowola (Agricultural Advisory Center) under the same conditions. Conditioning before milling consisted of adjusting the moisture content of the grains to $16 \%$, followed by a $24-\mathrm{h}$ rest in a closed container. The grains were milled in the CD1 Chopin laboratory mill (a simulator of industrial grinding).

\section{Flours analysis}

Flour was determined for protein content, wet gluten content, gluten elasticity, the Zeleny sedimentation volume and the falling number and ash content. The flour analyses were carried out in three replications.

Flour protein content $(\mathrm{N} \times 5.7)$ was determined according to the Kjeldahl method, wet gluten content and elasticity were determined according to the Polish Standard [PN A-74043:1994], the Zeleny sedimentation index, the falling number and ash content were determined according to International Standards [adequately ISO 5529:1992; ISO 3093:1982 and ISO 2171:1994].

\section{Dough analysis}

Alveograph properties of dough were determined four times according to ISO Standard [ISO 5530-4:2002] using a Chopin alveograph (Group Tripette and Renaud). The parameters obtained are: tenacity of the dough $(\mathrm{P})$ - the maximum over pressure, extensibility of the dough (L) - the average abscissa at rupture, strength of the dough (W) - the deformation energy of $1 \mathrm{~g}$ of dough, elasticity resistance of the dough (Ie)- equal $\mathrm{P}_{200}$ $\mathrm{P}_{\max }$ expressed in percentage, $\mathrm{P}_{200}$ is the pressure measured in the bubble after having blown $200 \mathrm{~mL}$ of air into the dough.

\section{Bread making and evaluation of breads}

The experimental baking was a small scale straight-dough baking test according to the Berlin Institute [Jakubczyk \& Haber, 1983]. The breads were prepared and baked in a laboratory oven with fermentation cabinet (Sadkiewicz Instruments, PL). Loaves of white pan bread were prepared after mixing, fermenting and proving the dough. The dough was fermented at $30^{\circ} \mathrm{C}$ and $75 \% \mathrm{RH}$ for $60 \mathrm{~min}$ (with $1 \mathrm{~min}$ transfixion after $30 \mathrm{~min}$ ) in a fermentation cabinet. Proving was performed at $30^{\circ} \mathrm{C}$ and $75 \% \mathrm{RH}$ in a proving cabinet in time required for optimal dough development. The loaves were baked at $230^{\circ} \mathrm{C}$ for $25 \mathrm{~min}$ in an oven (live steam was injected immediately after the loaves were placed in the oven). Baking tests were performed on each flour by using three replicates.

Textural properties of bread crumbs were tested by texture profile analysis (TPA) [Wang et al., 2002; Steffe, 1996]. Texture analysis of the crumb was performed on three slices taken from the centre of each loaf. The bread crumb samples (20x20x20 mm) from the centre of each slice were two times compressed by a capital equipped with a $25 \mathrm{~mm}$ plug. Twelve replicates of bread crumb sample were analysed. The parameters recorded were hardness, cohesiveness and gumminess.

\section{Statistical methods}

Statistical analyses were done at a significance level of $\alpha=0.05$ using Statistica by Statsoft.

To develop effective predictive model the stepwise regression procedure was applied. The regression equations were recorded using the stepwise backward method which employs a combination of the procedures used in the forward entry and backward removal methods. The determination coefficient and estimation standard deviation was defined. Additionally all regression relationships were analysed and only the significant ones were presented.

Canonical correlation was an additional procedure for assessing the relationship between two sets of variables presenting simultaneously wheat and bread properties. To estimate the significance of variables the $\chi^{2}$ test was applied.

\section{RESULTS}

The wheat cultivars used in this study varied in flour and dough alveograph properties, therefore bread produced differed in the loaf volume and breadcrumb texture (Table 1).

Wheat cultivar Koksa yielded the greatest volume of bread compared with the others cultivars. Also big loaf volume but significantly lower than that of Koksa was obtained when bread was produced from Jasna and Santa wheat cultivars. The smallest volume of bread was achieved when using flour from wheat cultivar Hezja. The medium loaf volume was recorded for bread produced flour from Nawra and Eta cultivars. Protein content, gluten content, gluten elasticity and the Zeleny sedimentation index of Koksa flour were $14.43 \%$, $33.6 \%, 11 \mathrm{~mm}$ and $51.7 \mathrm{~mL}$, respectively. The alveograph parameters of this wheat cultivar accounted for $\mathrm{P}=112 \mathrm{~mm}_{\mathrm{H} 20}$, $\mathrm{L}=114 \mathrm{~mm}, \mathrm{P} / \mathrm{L}=0.980$ and $\mathrm{W}=428 \times 10^{-4} \mathrm{~J}$. Flour protein content, flour gluten content, gluten elasticity, the Zeleny sedimentation index, the falling number and ash content of Hezja flour were $12.50 \%, 29.33 \%, 9 \mathrm{~mm}, 36 \mathrm{~mL}, 325 \mathrm{~s}$ and $0.568 \%$ respectively. Values of its alveograph parameters accounted for $\mathrm{P}=62 \mathrm{~mm}_{\mathrm{H} 20}, \mathrm{~L}=139, \mathrm{P} / \mathrm{L}=0.450$ and $\mathrm{W}=215 \times 10^{-4} \mathrm{~J}$.

In our study a multiple regression procedure indicated that there was more than one significant independent variable. The relationships between the studied parameters are given in Table 2 and the exemplary correlations between predicted and observed values are given in Figures 1a-d. The bread loaf volume was correlated with flour protein content $\left(\mathrm{R}^{2}=0.613\right)$ and also with flour gluten content $\left(\mathrm{R}^{2}=0.410\right)$ or with the Zeleny sedimentation index $\left(\mathrm{R}^{2}=0.532\right)$. The results indicated that good prediction could be achieved using the flour protein content and the ratio of the dough tenacity to 


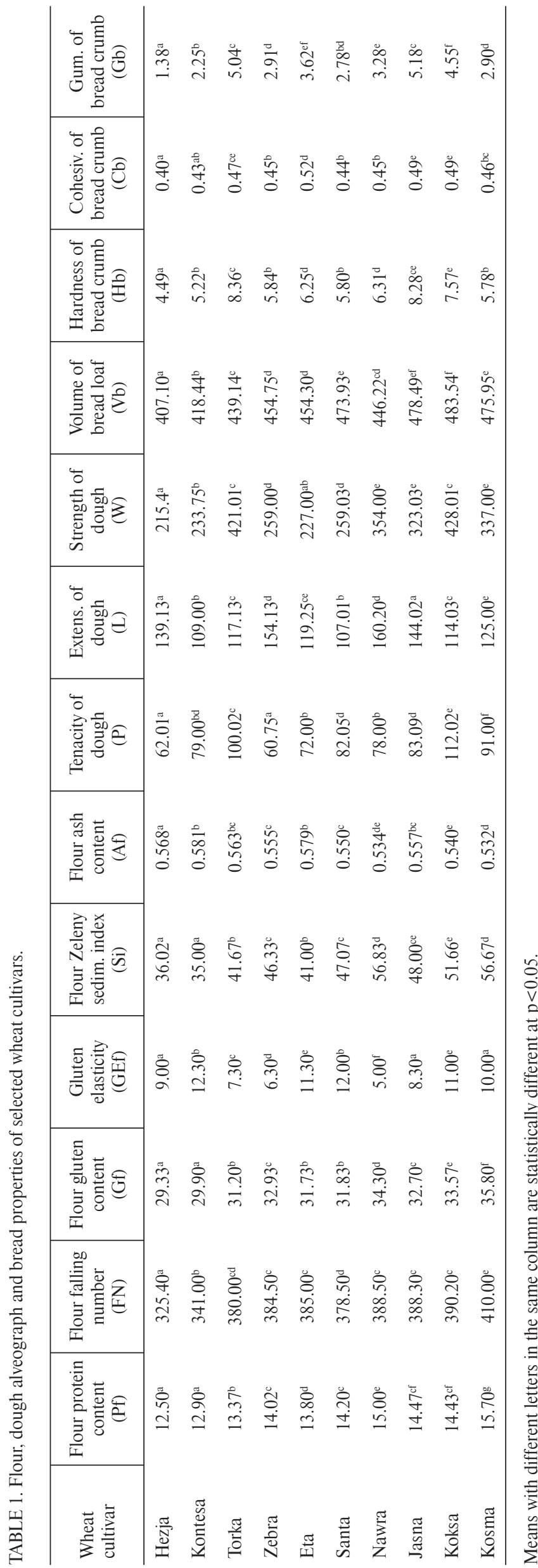

TABLE 2. Equations expressing bread properties.

\begin{tabular}{|c|c|c|c|c|}
\hline & Figure equation $(\mathrm{N}=120)$ & $\begin{array}{c}\text { Estim. } \\
\text { standard } \\
\text { error }\end{array}$ & R-square & p-value \\
\hline \multicolumn{5}{|c|}{ Bread loaf volume $\left(V_{b}\right)$} \\
\hline 1. & $\mathrm{~V}_{\mathrm{b}}=7.59 \times \mathrm{P}_{\mathrm{f}}+0.655 \times \mathrm{FN}-0.30 \mathrm{~L}$ & 12.080 & 0.769 & 0.0000 \\
\hline 2. & $\begin{array}{c}\mathrm{V}_{\mathrm{b}}=20.539 \times \mathrm{P}_{\mathrm{f}}+41.30 \times \mathrm{P} / \mathrm{L} \\
+137.642\end{array}$ & 13.698 & 0.701 & 0.0000 \\
\hline 3. & $\mathrm{~V}_{\mathrm{b}}=21.497 \times \mathrm{P}_{\mathrm{f}}+151.29$ & 15.519 & 0.613 & 0.0000 \\
\hline 4. & $\mathrm{~V}_{\mathrm{b}}=2.459 \times \mathrm{Si}+339.869$ & 17.070 & 0.532 & 0.0000 \\
\hline 5. & $\mathrm{~V}_{\mathrm{b}}=6.016 \times \mathrm{G}_{\mathrm{f}}+130.660$ & 18.554 & 0.410 & 0.0000 \\
\hline 6. & $\mathrm{~V}_{\mathrm{b}}=7.231 \times \mathrm{G}_{\mathrm{f}}+2.584 \times \mathrm{GE}_{\mathrm{f}}+66.819$ & 17.377 & 12 & 0.0000 \\
\hline \multicolumn{5}{|c|}{ Bread crumb hardness $\left(\mathrm{H}_{\mathrm{b}}\right)$} \\
\hline 1. & $\begin{aligned} \mathrm{H}_{\mathrm{b}}= & 0.0148 \times \mathrm{W}+0.0 \\
& +48.746 \times \mathrm{A}_{\mathrm{f}}-34.3\end{aligned}$ & 0.558 & 0.801 & 0.0000 \\
\hline 2. & $\begin{array}{c}\mathrm{H}_{\mathrm{b}}=0.0112 \times \mathrm{W}+0.008 \times \mathrm{FN} \\
-0.0473\end{array}$ & 0.792 & 0.597 & 0.0000 \\
\hline 3. & $\mathrm{H}_{\mathrm{b}}=0.013 \times \mathrm{W}+2.541$ & 0.804 & 81 & 0.0000 \\
\hline 4. & $\begin{array}{c}\mathrm{H}_{\mathrm{b}}=1.697 \times \mathrm{P} / \mathrm{L}- \\
1.175 \times \mathrm{P}_{\mathrm{f}}+0.064 \times \mathrm{FN}-2.477\end{array}$ & 0.852 & 0.538 & 0.0000 \\
\hline 5. & $\mathrm{H}_{\mathrm{b}}=0.1505 \times \mathrm{Ie}-1.77799$ & 0.879 & 0.500 & 0.0000 \\
\hline \multicolumn{5}{|c|}{ Bread crumb cohesiveness $\left(C_{b}\right)$} \\
\hline 1. & $\mathrm{C}_{\mathrm{b}}=0.002 \times \mathrm{FN}+1.462 \times \mathrm{A}_{\mathrm{f}}-0.962$ & 0.023 & 0.606 & 0.0000 \\
\hline \multicolumn{5}{|c|}{ Bread crumb gumminess $\left(G_{b}\right)$} \\
\hline 1. & $\begin{aligned} \mathrm{G}_{\mathrm{b}}= & 0.013 \times \mathrm{W}+0.0299 \times \mathrm{FN} \\
& +50.445 \times \mathrm{A}_{\mathrm{f}}-39.885\end{aligned}$ & 0.494 & 0.827 & 0.0000 \\
\hline 2. & $\mathrm{G}_{\mathrm{b}}=0.012 \times \mathrm{W}-0.339$ & 0.910 & 0.548 & 0.0000 \\
\hline 3. & $\begin{array}{c}\mathrm{G}_{\mathrm{b}}=0.054 \times \mathrm{P}+0.029 \times \mathrm{L}- \\
1.481 \times \mathrm{P}_{\mathrm{f}}+0.062 \times \mathrm{FN}_{\mathrm{f}}-7.218\end{array}$ & 0.518 & 0.811 & 0.0000 \\
\hline 4. & $\mathrm{G}_{\mathrm{b}}=0.024 \times \mathrm{L}+0.064 \times \mathrm{P}-4.952$ & 0.822 & 0.517 & 0.0000 \\
\hline
\end{tabular}

$\mathrm{V}_{\mathrm{b}}$ - Loaf bread volume, $\mathrm{cm}^{3}, \mathrm{H}_{\mathrm{b}}$ - Crumb hardness, N, $\mathrm{C}_{\mathrm{b}}$ - Crumb cohesiveness, -, $\mathrm{G}_{\mathrm{b}}-$ Crumb gumminess, $\mathrm{N}, \mathrm{A}_{\mathrm{f}}-$ Flour ash content, FN -Flour falling number, $\mathrm{s}, \mathrm{G}_{\mathrm{f}}-$ Flour gluten content, $\%, \mathrm{GE}_{\mathrm{f}}$ - Flour gluten elasticity, $\mathrm{mm}, \mathrm{P}_{\mathrm{f}}$ - Flour protein content, \%, Si- Zeleny sedim. index, $\mathrm{mL}$, Ie - Elasticity resistance, L- Extensibility, $\mathrm{mm}, \mathrm{P}-$ Tenacity, $\mathrm{mm}_{\mathrm{H} 20}$, WStrength, $10^{-4} \mathrm{~J}$.

extensibility $\left(\mathrm{R}^{2}=0.701\right)$, but the best prediction was achieved using flour protein content, the falling number, and dough extensibility $\left(\mathrm{R}^{2}=0.769\right)$, (Figure 1a).

The lowest hardness of the breadcrumb was achieved when bread was produced from flour of Hezja cultivar. Also low breadcrumb hardness but significantly higher produced Kontesa and Santa cultivars. Bread produced from flour of wheat cultivar Torka was characterised by the highest breadcrumb hardness. The high breadcrumb hardness was also noted for bread made of Jasna cultivar flour. The medium breadcrumb hardness was recorded for bread produced from Eta and Zebra cultivars flour. The flour protein content, flour gluten content, gluten elasticity, the Zeleny sedimentation index, the falling number and ash content of Torka flour were $13.37 \%$, $31.20 \%, 7 \mathrm{~mm}, 41.67 \mathrm{~mL}, 380 \mathrm{~s}$ and $0.563 \%$. The alveograph properties of this flour were as follows: $\mathrm{P}=100 \mathrm{~mm}_{\mathrm{H} 20}$, $\mathrm{L}=117 \mathrm{~mm}, \mathrm{P} / \mathrm{L}=0.85$ and $\mathrm{W}=421 \times 10^{-4} \mathrm{~J}$. 

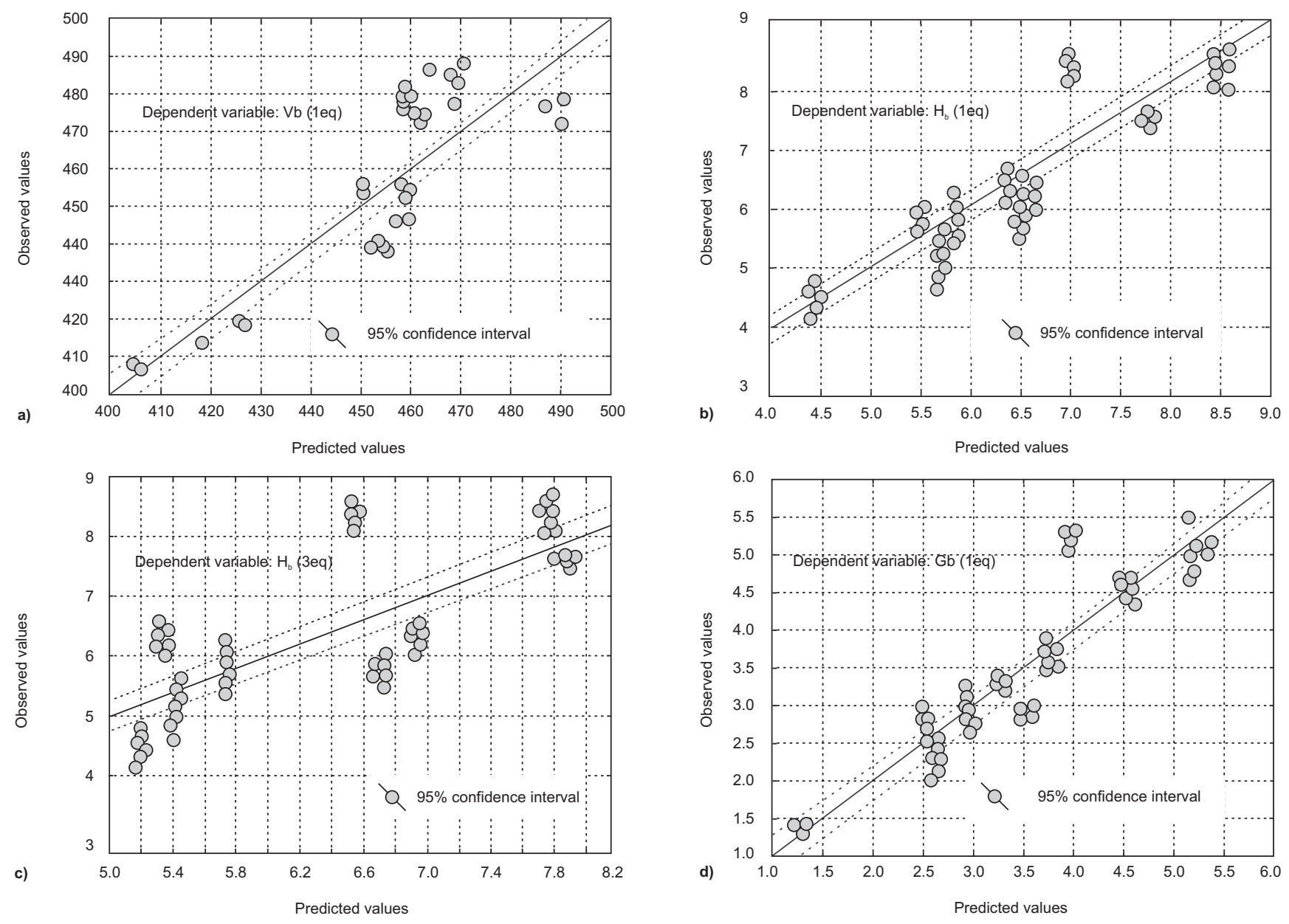

FIGURE 1. Predicted and observed values of selected equations of bread properties: a) prediction of bread volume (1 equation), b) prediction of breadcrumb hardness ( 1 equation), c) prediction of breadcrumb hardness (3 equation), and d) prediction of breadcrumb gumminess (1 equation).

The predictors of breadcrumb hardness are strength of the dough, the flour falling number, and ash content (Figure 1b). The coefficient of determination $\left(\mathrm{R}^{2}\right)$ determined in our study was equal to 0.801 . The $\mathrm{R}^{2}$ value indicates that the model fits the data very well. In addition the results indicated that only the strength of the dough was a good predictor of breadcrumb hardness $\left(\mathrm{R}^{2}=0.581\right)$, (Figure $\left.1 \mathrm{c}\right)$. Additionally, the stepwise regression indicated that the hardness of the breadcrumb depended significantly on the $\mathrm{P} / \mathrm{L}$ alveograph, protein content, and the falling number of flour $\left(\mathrm{R}^{2}=0.538\right)$.

Cohesiveness of the breadcrumb was the least related to flour and dough properties; there was only one regression line predicting this feature. The results indicated that the cohesiveness of the breadcrumb depended significantly on the flour falling number and the flour ash content $\left(\mathrm{R}^{2}=0.606\right)$ The next parameter of the breadcrumb textural properties was breadcrumb gumminess. Bread produced from flour of wheat cultivar Hezja was characterized by the lowest value of breadcrumb gumminess, whereas that made of flours of wheat cultivars Jasna and Torka by the highest values of this parameter. The medium values of breadcrumb gumminess were recorded for bread produced from flours of Nawra and Zebra cultivars. Flour protein content, flour gluten content, gluten elasticity, the Zeleny sedimentation index, the falling number and ash content of Jasna flour were 14.47\%, 32.70\%,
$8 \mathrm{~mm}, 48.00 \mathrm{~mL}, 388 \mathrm{~s}$, and $0.557 \%$, respectively. The alveograph properties of this flour accounted for $\mathrm{P}=83 \mathrm{~mm}_{\mathrm{H} 20}$, $\mathrm{L}=144 \mathrm{~mm}, \mathrm{P} / \mathrm{L}=0.580$ and $\mathrm{W}=323$.

In our study, the breadcrumb gumminess depended also on dough and flour properties. Breadcrumb gumminess could be described in four regression equations (Table 2). The regression equation enables the best prediction of breadcrumb gumminess, given the strength of dough, the falling number of flour, and ash content of flour $\left(\mathrm{R}^{2}=0.827\right)$ (Figure 1d). Consideration could also be given to the regression line for the strength of dough $\left(\mathrm{R}^{2}=0.548\right)$. Gumminess of the breadcrumb depended also on the tenacity and extensibility of the dough, the flour protein content, and the falling number $\left(\mathrm{R}^{2}=0.811\right)$.

In quality assessment of bread very important are both bread loaf volume and breadcrumb texture. The Santa cultivar gave bread with enough good volume and not too high hardness. The flour protein content, flour gluten content, gluten elasticity, the Zeleny sedimentation index, the falling number and ash content of Santa flour were 14.20\%, 31.80\%, $12 \mathrm{~mm}$, $47.00 \mathrm{~mL}, 378 \mathrm{~s}, 0.550 \%$, respectively. The alveograph properties of this flour were equal to $\mathrm{P}=82 \mathrm{~mm}_{\mathrm{H} 20}, \mathrm{~L}=107 \mathrm{~mm}$, $\mathrm{W}=259, \mathrm{P} / \mathrm{L}=0.760$.

Canonical correlation was an additional procedure for assessing the relationship between the two sets of variables present- 

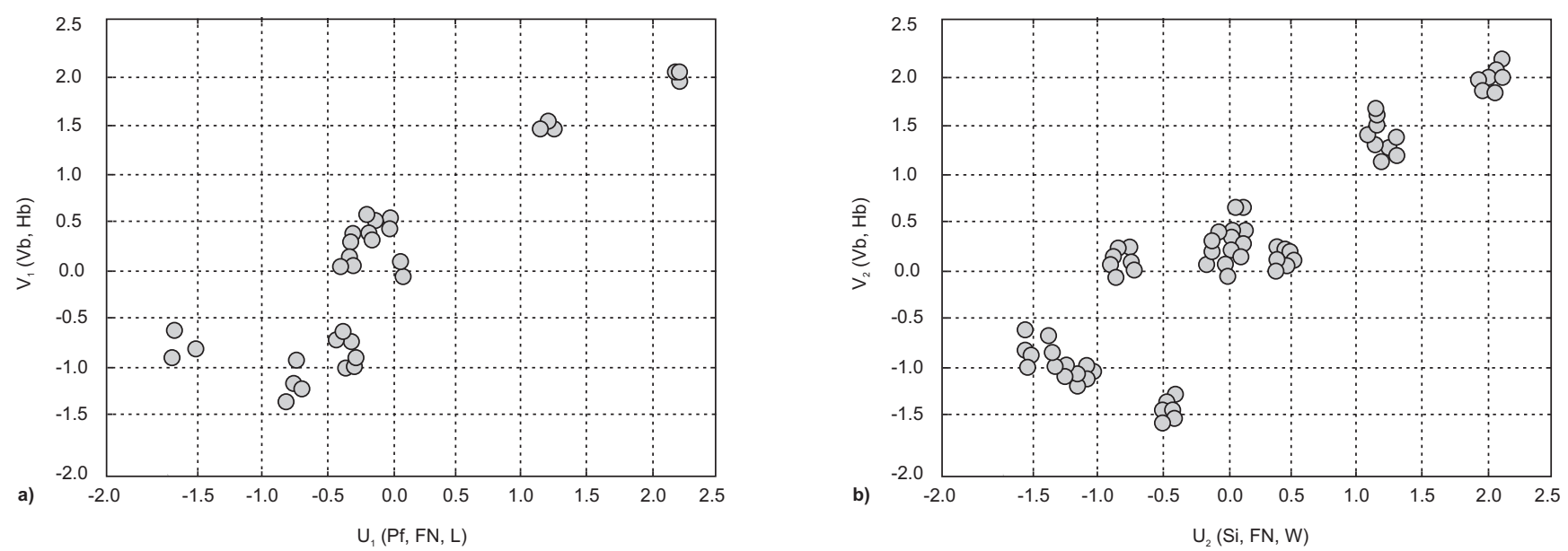

FIGURE 2. Canonical relationships between supplementary variables: a) supplementary variables $\mathrm{U}_{1}$ and b) supplementary variables $\mathrm{U}_{2}$ and $\mathrm{V}_{2}$.

ed, raw material and bread properties. The results showed that the best prediction line could be obtained for bread loaf volume and breadcrumb hardness. This analysis allowed the creation of two simple models, which could predict bread loaf volume and breadcrumb hardness simultaneously. The first model showed that the most important flour and dough properties for simultaneous prediction of bread loaf volume and crumb hardness were the Zeleny sedimentation index, the falling number, and strength of the dough. The statistically significant group of canonical variables was obtained and shown bellow:

$$
\begin{aligned}
& \mathrm{U}_{1}=0.553 \times \mathrm{Si}-0.942 \times \mathrm{FN}-0.629 \times \mathrm{W} \\
& \mathrm{V}_{1}=-0.405 \times \mathrm{V}_{\mathrm{b}}-0.728 \times \mathrm{H}_{\mathrm{b}}
\end{aligned}
$$

Supplementary variables $\mathrm{U}_{1}$ and $\mathrm{V}_{1}$ are highly canonically correlated $(R=0.875$, Figure $2 a)$, and represent respectively flour, dough alveograph and bread properties.

The second model shows that simultaneous prediction of bread loaf volume and crumb hardness is also possible using the flour protein content, the falling number and dough extensibility:

$$
\begin{aligned}
& \mathrm{U}_{2}=-0.238 \times \mathrm{P}_{\mathrm{f}}-0.785 \times \mathrm{FN}+0.24 \times \mathrm{L} \\
& \mathrm{V}_{2}=-0.969 \times \mathrm{V}_{\mathrm{b}}-0.057 \times \mathrm{H}_{\mathrm{b}}
\end{aligned}
$$

Supplementary variables $\mathrm{U}_{2}$ and $\mathrm{V}_{2}$ are also highly canonically correlated $(R=0.877$, Figure $2 b)$, and represent respectively flour, dough alveograph and bread properties.

\section{DISCUSSION}

In our study the stepwise regression procedure was essential to develop effective predictive models for bread loaf volume and breadcrumb texture. This method is still poorly used in the bakery field. Only Butt et al. [2001] used the stepwise regression procedure for assessing the significant variables contributing to bread loaf volume, total bread scores, and chapatti scores. Konopka et al. [2004] used the regression procedure for predicting water absorption and bread volume. Collar et al. [1999] also used this statistical method for formulating dough properties by addition of a hydrocolloid. In our study, the bread loaf volume was related to the flour protein content or the Zeleny sedimentation index, but the best prediction was achieved by using the flour protein content, the falling number, and the dough extensibility. Many researches have shown a simple positive correlation between protein content and bread volume [Perez Borla et al., 2004; Wilkstrőm \& Bohlin, 1999; Færgestad et al., 1999] and between sedimentation index and bread volume [Duma, 1992]. It has previously been shown that alveograph properties also influence bread volume [Færgestad et al., 2000; Janssen et al., 1996]. In turn, Andersson et al. [1994] predicted loaf volume using grain, flour, and dough properties. Their prediction equation included grain and flour protein content, farinograph dough development, stability and breakdown, an extensograph area, peak height, and length. However, there is no model equation predicting a bread volume that includes both flour and alveograph properties.

There are only a few research works addressing a relation between the rheological properties of dough and the properties of the breadcrumb [Tronsomo et al., 2003; Scanlon et al., 2000; Janssen et al., 1996]. In addition, the authors did not determine the predicting power of both the flour and the alveographic dough properties, for assessing the textural properties of the breadcrumb.

Exemplarily Tronsomo et al. [2003] and Janssen et al. [1996] described a relation between the rheological properties of the dough and breadcrumb structures. Tronsomo et al. [2003] affirmed that the porosity of bread was determined by the rheological properties of dough. Janssen et al. [1996] explained that the dough from very strong flour was more elastic and less extensible, which was a result of a very strong intermolecular interaction. Therefore, bread baked from such dough was more firm.

Only Scanlon et al. [2000] compared the mechanical properties (textural) of breadcrumb prepared from flours of different dough strengths. These authors noticed that breadcrumbs made from a flour possessing extra strong dough properties was stronger than breadcrumbs made from the more conventional red spring wheat flour, and there was 
an indication that the extra strong flour breadcrumb specimens were more firm. Additionally, the authors did not determine the relation between alveographic parameters of dough and textural properties of breadcrumb, which could have been useful on an industrial scale.

In our study, a multiple regression procedure indicated that there was more than one significant independent variable. The results showed that the significant predictors of textural properties were both flour and alveograph dough properties.

The results of the canonical analysis allowed the creation of simple models, which showed that both flour and alveograph dough properties were important for simultaneously predicting bread loaf volume and breadcrumb hardness. The models that have been developed could be useful in industries and will make up the essential supplement of existing investigation, because the relationship between two sets of variables defining wheat and bread properties is poor. Only Butt et al. [2001] have characterised the group of connections between the end use quality (the bread volume, the bread, and chapatti scores) and the bio-chemical and physicochemical properties of raw material.

\section{CONCLUSIONS}

The studied wheat cultivars varied in flour and dough alveograph properties, therefore the bread produced was differentiated in the loaf volume and breadcrumb texture. High values of loaf volume were achieved for bread made of flour of Koksa, Jasna, and Santa wheat cultivars, whereas the lowest ones - for bread produced from flour of wheat cultivar Hezja. The low hardness of the breadcrumb was noted for bread produced from flour of Hezja, Kontesa and Santa cultivars, whereas the highest one for bread produced from wheat cultivar Torka. The best expected quality of bread was achieved using Santa cultivar, which gave bread with enough good volume and not too high hardness.

The results showed that the significant predictors of bread loaf volume alone and with crumb texture were the dough alveograph and flour properties. The results of the canonical analysis allowed the creation of two simple models, which could simultaneously predict bread loaf volume and breadcrumb hardness. In these models the most important flour and dough properties were the Zeleny sedimentation index, the falling number, and the strength of the dough or the flour protein content, the falling number, and the dough extensibility. This knowledge is very important to obtain the quality expected of a breadcrumb, with good loaf volume and crumb texture. The results are especially interesting for industries because flour and alveograph parameters are obligatorily used as quality indicators of wheat.

\section{REFERENCES}

1. Andersson R., Hamalainen M., Aman P., Predictive modelling of the bread-making performance and dough properties of wheat. J. Cereal Sci., 1994, 20, 129-138.

2. Armero E., Collar C., Texture properties of formulated wheat doughs. Relationships with dough and bread technological quality. Z. Lebensm. Unters Forsch. A, 1997, 204, 136-145.
3. Bloksma A.H., Rheology of the breadmaking process. Cereal Food World, 1990, 35, 228-236.

4. Butt M.S., Anjum F.M., van Zuilichem D.J., Shaheen M., Development of predictive models for end-use quality of commercial gluten flours. Int. J. Food Sci. Technol., 2001, 36, 433-440.

5. Cacak-Pietrzak G., Ceglińska A., Haber T., Nowakowska D., Baking value of winter wheat lineage in comparison with chosen wheat variety. Przegl. Zboż. Młyn., 1999, 8, 15-17 (in Polish).

6. Collar C., Andreu P., Martinez J.C., Armero E., Optimization of hydrocolloid addition to improve bread dough functionality: a response surface methodology study. Food Hydrocoll., 1999, 13, 467-475.

7. Czubaszek A., Subda H., Kowalska M., Korczak B., Żmijewski M., Karolini-Skardzińska Z., Chemical and biochemical evaluation of chosen winter wheat variety flour. Żywn- Nauk. Technol. Jakość, 2001, 1, 77-84 (in Polish).

8. Dowell F.E., Maghirang E.B., Pierce R.O., Lookhart G.L., Bean S.R., Xie F., Caley M.S., Wilson J.D., Seabourn B.W., Ram M.S., Park S.H., Chung O.K., Relationship of bread quality to kernel, flour, and dough properties. Cereal Chem., 2008, 85, 82-91.

9. Duma, Z., Sedimentation index - technological quality value of grain and flour (e.g. Polish). Przegl. Zboż. Młyn., 1992, 2, 13-14 (in Polish).

10. Dziki D., Laskowski J., Evaluation of dough rheological properties by use of consistograph and alveograph. Acta Agrophys., 2003, 82, 23-32 (in. Polish).

11. Edwards N.M., Preston K.R., Paulley F.G., Gianibelli M.C., McCaig T.N., Clarke J.M., Ames N.P., Dexter J.E., Hearth bread baking quality of durum wheat varying in protein composition and physical dough properties. J Sci. Food Agric. 2007, 87, 2000-2011.

12. Færgestad E.M., Magnus E.M., Sahlström Næs, T., Influence of flour quality and baking process on hearth bread characteristics made using gentle mixing. J. Cereal Sci., 1999, 30, 61-70.

13. Færgestad E.M., Molteberg E.L., Magnus M., Interrelationships of protein composition, protein level, baking process and the characteristics of hearth bread and pan bread. J. Cereal Sci., 2000, 31, 309-320.

14. Gras P.W., Carpenter H.C., Anderssen R.S., Modelling the developmental rheology of wheat-flour dough using extension tests. J. Cereal Sci., 2000, 31, 1-13.

15. ISO 2171: 1994. Cereal and cereal products. Determination of ash content.

16. ISO 3093: 1982. Cereals - Determination of falling number. ISO 5529: 1992. Wheat - Determination of sedimentation index - Zeleny test.

17. ISO 5530-4: 2002. Wheat flour (Triticum aestivum L.). Physical characteristics of doughs. Determination of rheological properties using an alveograph.

18. Jakubczyk T., Haber T., Analysis of Cereals and Cereal Products. 1983, Wydawnictwo SGGW-AR, pp. 267-274 (in Polish).

19. Janssen A.M., Van Vliet T., Vereiken J.M., Fundamental and empirical rheological behaviour of wheat flour doughs and comparison with bread making performance. J. Cereal Sci., 1996, 23, 43-54.

20. Karolini-Skardzińska Z., Subda H., Korczak B., Kowalska M., Żmijewski M., Czubaszek A., Technological evaluation of grain and flour of selected cultivars of winter wheat. Żywn. Nauk. Technol. Jakość, 2001, 2, 69-77 (in Polish).

21. Konopka I., Fornal Ł., Abramczyk D., Rothkaehl J., Rotkiewicz D., Statistical evaluation of different technological and rheologi- 
cal tests of Polish wheat varieties for bread volume prediction. Int. J. Food Sci. Technol., 2004, 39, 11-20.

22. Laskowski J., Różyło R., Influence of starch damage extent in wheat flour on rheological (alveograph) properties of dough. Acta Agrophys., 2004, 4, 373-380 (in Polish).

23. Oliver J.R., Allen H.M., The prediction of bread baking performance using the farinograph and extensograph. J. Cereal Sci., 1992, 15, 79-89.

24. Perez Borla O.P., Leonor Motta E., Saiza A., Fritza R., Quality parameters and baking performance of commercial gluten flours. Lebensm.-Wiss. u.-Technol., 2004, 37, 723-729.

25. Phan-Thien N., Safari-Ardi M., Linear viscoelastic properties of flour-water doughs at different water concentrations. J. NonNewton. Fluid Mech., 1998, 74, 137-150.

26. PN A-74043: 1994. Determination of wet gluten content (in Polish).

27. Scanlon M.G., Sapirstein H.D., Fahloul D., Mechanical properties of bread crumb prepared from flours of different dough strength. J. Cereal Sci., 2000, 32, 235-243.
28. Stampfli L., Nersten B., Emulsifiers in bread making. Food Chem., 1995, 52, 353-360.

29. Steffe J.F., Rheological methods in food process engineering. 1996, Freeman Press USA, pp. 71-75.

30. Tronsomo K.M., Magnus E.M., Baardseth P., Schofield J.D., Aamond A., Færgestad E.M., Comparison of small and large deformation rheological properties of wheat dough and gluten. Cereal Chem., 2003, 80, 587-595.

31. Wang J., Rosell C.M., Benedito de Barber C., Effect of the addition of different fibres on wheat dough performance and bread quality. Food Chem., 2002, 79, 222-226.

32. Wilkstrőm K., Bohlin L., Extensional flow studies of wheat flour dough. II. Experimental method for measurements in constant extension rate squeezing flow and application to flours varying in breadmaking performance. J Cereal Sci., 1999, 29, 227-234.

Received January 2010. Revision received April and accepted May 2010. 
